political ownership of the land. To whatever degree the Paramount's powers may be qualified or dispersed he retains (as Dr. Richards states) the spiritual overlordship of the whole Bemba territory. The people's belief in his supernatural powers is the sanction for his political authority and economic prerogatives. However much the belief has weakened in these days, Dr. Richards found in 1934 that it was still the dominant force behind the politico-economic machine.

Mr. Brelsford discusses the subject from an administrative point of view. The Government finds it necessary to change the boundaries of districts which cut across agricultural schemes, the demarcation of game reserves, and plans for closer settlement. The establishment of Treasuries and the grouping of tribal units lead to agitation in favour of the return of erstwhile conquered peoples to their original allegiance and thus to their removal from within the Bemba chiefdom. The question apparently in Mr. Brelsford's mind is whether Government should be deterred from making such changes by consideration of the spiritual overlordship of the Bemba Paramount. An examination of various episodes in the history of the region leads him to believe that too much stress has been laid upon the theory of the sanctity and the spiritual attachment of chiefs to their areas. The spiritual association is brittle; it becomes permanent only when backed by political control; spiritual ownership is dependent upon political ownership. The ultimate sanction of authority over land was not religious but lay in the political and military power of the Bemba; and now that they have lost that. power areas held by them can be detached without 'dislocations visiting the land'. We take him to mean by that phrase that if and when land is detached from the Bemba the inhabitants of it may still believe that the productivity of the soil is due to the powers of local tutelary deities and so will not be rudely shaken out of traditional beliefs. In his argument he finds support in the historical fact that spiritual and political owners are not necessarily identical. "In our future relations with chiefs and their areas (he concludes) I think that the point of effective occupation can be heavily stressed without interfering unduly with religious or spiritual claims, although of course personal or tribal pride might be offended.'

\title{
An Example of African Juristic Distinctions
}

When last April we reviewed Dr. Max Gluckman's Essays on Lozi Land and Royal Property we omitted to refer to the distinction drawn in Lozi law between yamba and zabulena. Dr. Gluckman says that, so far as he knows, this interesting juristic distinction has not been recorded elsewhere in Africa; and one purpose of this note is to invite our readers to tell us whether they have come across it in their studies of other tribes.

The bringing of tribute to the king and the reciprocal giving of gifts by the king were one of the chief mechanisms by which goods were exchanged in Loziland. Groups of people were ordered to produce for the king certain quantities of particular goods, according to the raw materials existent in their districts, their particular skills, or the nature of their crops or herds. People in the plain brought such things as reeds and fish; those in bush country brought bark-string, nets, and grain; the Lunda people brought dug-out canoes. All these goods were named yamba, 'tribute'. The payment was compulsory; anyone who failed to render his quota was punished. The king sent out councillors to collect the tribute. When it arrived at the capital, a portion was taken by the king and the rest was divided among the people who were present at the court, whether members of the royal family, councillors, or commoners. And the king rewarded the tributaries by gifts-to those who lacked cattle he would give cows. It appears that people could give their labour as an equivalent for goods.

In addition to, and distinct from, yamba, the king had the right to certain things which were called zabulena (Sotho, lintho tsa borena, 'things of chieftainship ') or zasilena. Dr. 
Gluckman gives a complete list of them; they include lion and leopard skins, eland tails, parts cut from the unskinned carcass of a hippopotamus. People could not keep or use a single ' kingly thing' without special permission. If a man killed an eland and did not take the tail to the king he would be punished-for eland tails were the great prerogative of kingship. If a hunter killed an elephant, he was bound to take both tusks to the king who kept the right tusk and gave the left back to the hunter. The killer of a lion brought the skin and received ten hoes; the killer of a leopard got five hoes in return for the skin. People were under no compulsion to hunt these animals in order to provide zabulena. Tribute was given back to the people in some form; zabulena remained with the king or were distributed only to special persons; the rewards he gave came from the tribute goods. Dr. Gluckman appositely compares the prerogative right of the English Crown to all white wild unmarked swans and in whales and sturgeon which are taken in the seas 'forming parcel of the dominions of the Crown'.

A further distinction must be drawn between namba, zabulena, and limpho. Limpho are ' gifts' freely offered to the king without any compulsion; thus many people bring him some of the fish from their first catch.

In I 906 Lewanika, the Paramount Chief (king), proclaimed the freedom of all slaves but reserved the right to call up men to labour unpaid for twelve days in a year. In 1925 Yeta III agreed to surrender the right to free labour in return for an annual sum of $£ 2,500$. A clause of his proclamation also abolished namba. The Paramount Chief continued to send out councillors to collect various things which he required; but people were no longer compelled to render them as tribute but were paid for them: a cash transaction took the place of an enforced levy.

An important legal question arises out of the 1925 proclamation. It formally abolishes namba, 'tribute', and says nothing about zabulena. Probably the British Government in agreeing to compensate the Paramount Chief and councillors for the loss of their dues intended that they should no longer receive any goods or labour (except elephant tusks) for which they did not pay cash. The Government, says Dr. Gluckman, did not then know the distinction between yamba and zabulena; but it is hardly open to doubt that it was present to the mind of the Paramount Chief and that he did not intend to give up his right to zabulena. "Whether legally, in view of the different connotations of the word " tribute" in the minds of the two parties, the Paramount can be held to have given up his rights to kingly things under the agreement, is a question for a lawyer, not a sociologist', Dr. Gluckman writes. 'But on the basis of the distinction which I have set out above, the Provincial Administration in Barotseland has now granted the Paramount's claim to half of the hides of all hippo killed in the Province.' Our only concern here is the extent to which other African peoples discriminate between 'tribute' and 'kingly things'. It may be observed that namba is not a Sotho word as zabulena is. Does this indicate that zabulena were imposed by the Sotho-speaking Makololo conquerers in addition to the namba already paid by the Luyi whom they subdued?

\section{Personal}

Ar its meeting on 24 October the Bureau received, and most regretfully accepted, the resignation of Dr. J. H. Oldham. We have not the space to write adequately at present of Dr. Oldham's services; it must suffice to say now that, apart from its technical side, the Institute owes more to him than to any other single man.

Professor C. Daryll Forde has been appointed to the chair of Anthropology at University College, London, but will continue to serve the Institute as Director. He thus returns to the College where he was first a student and later a junior member of the staff. His earliest field-studies were carried on for two years in America, among the Yuma of the Lower 